\title{
VERIFICATION OF AN ARCHAIC AGE OCCUPATION ON BARBADOS, SOUTHERN LESSER ANTILLES
}

\author{
Scott M Fitzpatrick \\ Department of Sociology and Anthropology, NC State University, Raleigh, North Carolina, USA. \\ Email: scott_fitzpatrick@ncsu.edu.
}

\begin{abstract}
The Caribbean Archaic Age (about 3000-500 BC) is thought to represent the earliest migration of humans from South America into the Lesser Antilles. However, there is a conspicuous absence of these early sites on islands south of the Guadeloupe Passage. To date, only a single radiocarbon date derived from a Queen conch (Strombus [Eustrombus] gigas) shell at the Heywoods site on Barbados was indicative of an Archaic occupation in the southern Antilles apart from a scattering of poorly reported (and mostly undated) sites. Given a number of issues associated with reliance on a single date to establish a cultural horizon, along with other problems derived from possible carbonate cement contamination and dating marine shells of a longer-lived species such as Queen conch, 2 additional samples were taken from the same unit and context at Heywoods to confirm whether the site is truly representative of an occupation during the Archaic Age. Results from a Queen conch shell adze in Context 7 dated to 2530-2200 BC $(2 \sigma)$ and overlaps with the only other Archaic date from the site dating to $2320-1750 \mathrm{cal} \mathrm{BC}$, while a juvenile specimen of the same species from Context 8 at 3280-2940 BC $(2 \sigma)$ indicates that Barbados may have been settled even earlier. This suggests that Heywoods may be the oldest site between Trinidad and Puerto Rico. While further confirmation is required, these new dates have implications for understanding the nature of migratory ventures in the Caribbean, such as whether the "Southward Route" hypothesis-which postulates that earlier migration events from South America during the Ceramic Age (beginning 500 BC) initially bypassed the southern Lesser Antilles-also applies to the Archaic, and if other phenomena such as active volcanism may have played a role in structuring settlement patterns. Questions also remain as to why Heywoods does not exhibit the typical lithic Archaic tool kit.
\end{abstract}

\section{INTRODUCTION}

Some of the more central questions in Caribbean archaeology revolve around where peoples who settled the Antillean chain of islands originated from, their most probable routes of migration, and the timing of such ventures (Rouse 1986; Keegan 1994, 1995, 2000; Callaghan 2001, 2003). Over a century of archaeological research in the Caribbean has led to a series of culture history divisions representing 3 main, but not necessarily mutually exclusive, phases of occupation. The earliest evidence for human colonization of the Antillean chain of islands may date to as early as around 5000$4800 \mathrm{BC}$ when Lithic and/or Archaic peoples first arrived in Cuba, Hispaniola, and possibly Puerto Rico. While Trinidad in the south was settled even earlier $\sim 6000 \mathrm{BC}$, the island exhibits continentally derived flora and fauna, a reflection of its connection to the South American mainland during the Last Glacial Maximum (Figure 1). It should be noted that Trinidad today is only between 12-22 $\mathrm{km}$ from the mainland and was connected in the past, making its colonization history different than others in the Antilles. In addition, the biota of Tobago, only about $30 \mathrm{~km}$ northwest of Trinidad, is also clearly more continental in contrast to the oceanic biotas found in the Antilles from Grenada northward (Steadman and Stokes 2002:340). Nonetheless, the earliest Archaic date from Tobago at the Milford 1 site is only $\sim 1000-800 \mathrm{BC}^{1}$ (though it could be earlier $2200 \mathrm{BC}$; see Boomert 2000; Steadman and Stokes 2002), while Trinidad has dates from Banwari Trace going back to $\sim 6200$ 5800 BC (see Boomert 2000; Fitzpatrick 2006:395).

Regardless, these Lithic groups, sometimes referred to as Casimiroid (see Rouse 1992; Petersen et al. 2004:32), are thought to have originated from somewhere in Mesoamerica (Rouse 1992:69; Keegan 1994; Wilson et al. 1998; but see Callaghan 2003 and Lalueza-Fox et al. 2003 for a possible South American origin). Archaic peoples from South America (or "Ortoiroid") (see Rouse 1986,

\footnotetext{
${ }^{1}$ In Fitzpatrick (2006:394-5), this date was misreported as 2950-2770 BC instead of BP as originally shown in Steadman and Stokes $(2002: 345-6)$.
} 


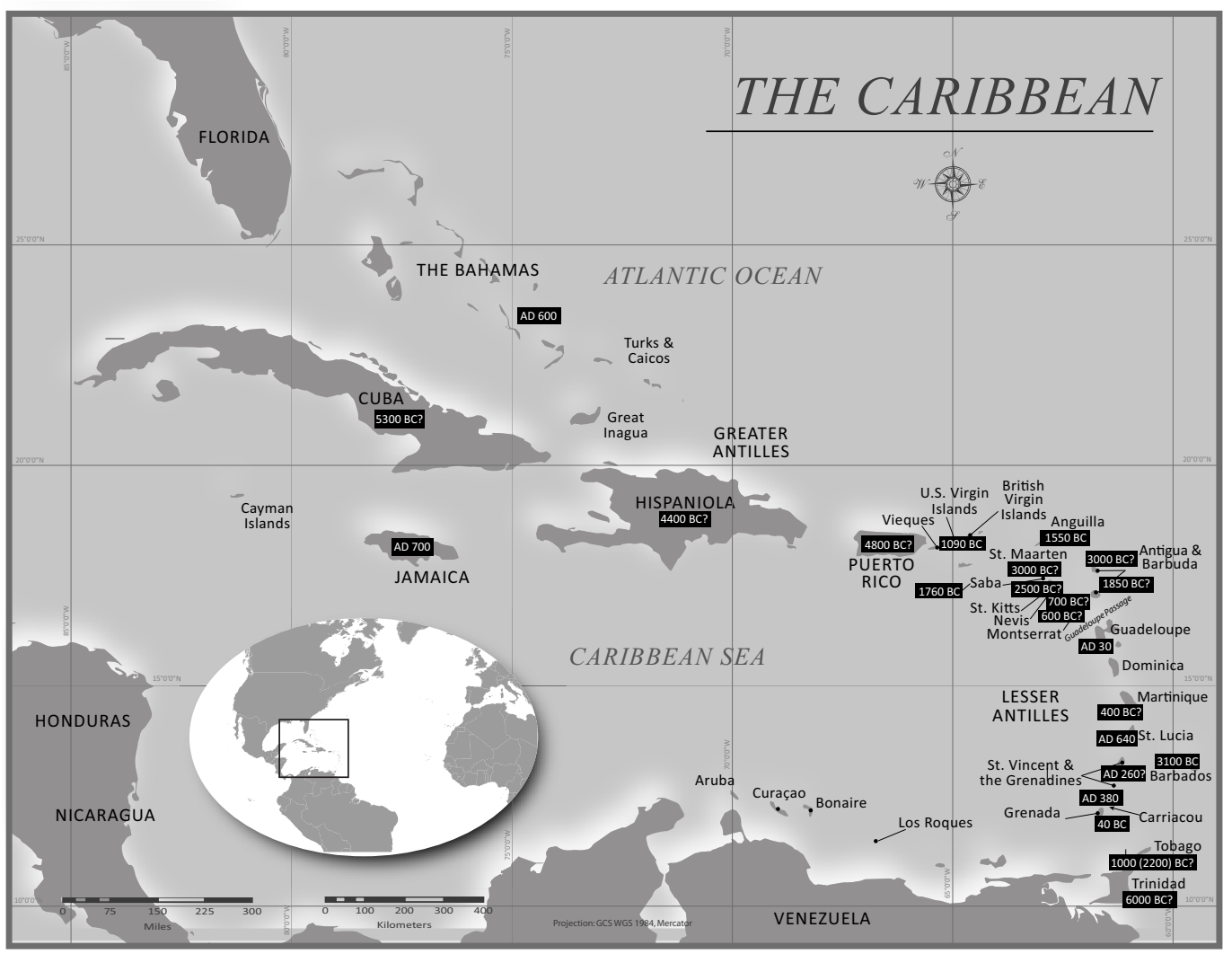

Figure 1 Map of the Caribbean showing the earliest acceptable (midrange, $2 \sigma$ ) ${ }^{14} \mathrm{C}$ dates in the Caribbean

1992; Petersen et al. 2004:32) are then thought to have occupied the Lesser Antilles sometime between about 3000 and $500 \mathrm{BC}$ (Wilson 2007:45-55).

Currently, only a few Archaic age sites in the Lesser Antilles south of the Guadaloupe Passage have been identified, including one on Guadeloupe reported to have shell and lithic tools (but not described in detail; see Richard 1994), 2 small sites on Martinique (Allaire and Mattioni 1983), one on St. Vincent with lithics that remains undated and is considered somewhat dubious (Keegan 1994: 266; Callaghan 2010), and the Heywoods site on Barbados, which was reported to have Archaicstyle celts/adzes and associated with a single ${ }^{14} \mathrm{C}$ assay (Drewett 2007). Archaic groups then seem to be followed by a new migration of people(s) referred to as "Saladoid" who voyaged from South America beginning around $500 \mathrm{BC}$ and either displaced or integrated with remnant Archaic populations or arrived to find them already gone.

It is generally accepted that those peoples who first settled the Lesser Antilles during the Archaic Age around $3000 \mathrm{BC}$, as well as subsequent Saladoid groups $\sim 500 \mathrm{BC}$, migrated from somewhere along the South American littoral, venturing northward through Trinidad, Tobago, and the Lesser Antilles in a stepping-stone fashion. However, a review of ${ }^{14} \mathrm{C}$ chronologies from the islands using a chronometric hygiene approach (Fitzpatrick 2006) showed that the earliest Saladoid settlement dates were found in the northern Antilles. This seemed to support earlier conclusions by Callaghan (2003), whose seafaring simulations demonstrated that migrants would have initially bypassed the 
southern Antilles given oceanographic conditions pushing vessels north and westward (see also Keegan 2000). Continued research on the subject in the Grenadines has failed to locate any sites that date earlier than cal AD 380 (e.g. Fitzpatrick et al. 2009; Fitzpatrick and Giovas 2011), and none in the southern Caribbean that date prior to around AD 1 with the possible exception of a handful of dates from Grenada at the Pearls site and Goddard on Barbados, both of which have issues with secure stratigraphic contexts. This reinforces the possibility that early Saladoid migrants reached the northern Antilles first and then ventured south, a process that has been termed the "Southward Route" hypothesis (Fitzpatrick et al. 2010).

While this hypothesis was originally proposed to explain Saladoid migration during the Ceramic Age, it is interesting to note that the same trend generally holds true for the Archaic Age where nearly all of the sites north of Trinidad that date between $~ 3000-500 \mathrm{BC}$ occur north of the Guadeloupe Passage. The exception to this comes from Milford I on Tobago, which dates to at least 1000 BC (Steadman and Stokes 2002) if not earlier (Boomert 2000) ${ }^{2}$ and Heywoods on Barbados (Drewett 1993). However, Buccament on St. Vincent was reported to contain Archaic-style lithic flakes but has no associated ${ }^{14} \mathrm{C}$ dates and little other artifactual evidence (Hackenberger 1991). As such, the site's antiquity remains ambiguous. Apart from Tobago, that leaves just a single site in the southern Lesser Antilles at Heywoods that has an Archaic age earlier than $\sim 1000 \mathrm{BC}$ and which is derived from an in situ sample.

In 1991, Peter Drewett (1993) recovered 2 Queen conch (Strombus [Eustrombus] gigas) ${ }^{3}$ adzes reminiscent of Archaic tools and numerous $S$. (Eustrombus) gigas shells from Context 8 in Trench 39 at a depth of approximately $140-150 \mathrm{~cm}$ bs. An associated Queen conch shell was dated to $2320 \pm 100$ (I-16,840) with a "calibrated age of 1630 BC." Drewett (2007:9) did note that pottery sherds were concentrated in the upper strata and also found within the proposed Archaic context in low quantities, but suggested that "they may well have sunk through the soft deposits or been taken down the profile by land crabs." Subsequent excavations at Heywoods in 1995 as part of a salvage recovery project I helped to direct, which was related to the development of a large resort and marina known as Port St. Charles, was focused in part on discovering additional Archaic material. While no obvious evidence of an Archaic occupation was located, subsequent work at the site by Drewett (2007) recovered 10 conch lip shell tools similar to the two from Trench 39, with another 220 adzes later found during marina construction.

Given the uniqueness of the date for the southern Caribbean, Callaghan (2010:141) suggested that "the single shell celt dating to $1630 \mathrm{BC}$ on Barbados, a nonvolcanic island, is suggestive of an early settlement during the Archaic Age, but a more well-developed chronology and additional artifactual evidence are required to determine the age and extent of settlement during this time." Coupled with a host of issues related to the dating of marine and longer-lived mollusk taxa and concerns of having possibly dated a specimen with carbonate cement encrustations using conventional dating techniques (i.e. older limestone veneer inadvertently included in the dating of the shell itself), 2 additional samples from Trench 39 were submitted to Beta Analytic, Inc. (Miami, USA) for dating. Below, I provide a brief chronological and geographical context for Archaic occupation in the Antilles, describe past research at Heywoods, and then discuss the newly acquired ${ }^{14} \mathrm{C}$ dates from the site.

\footnotetext{
${ }^{2}$ As Steadman and Stokes (2002:345-6) noted, these samples were derived from bulk shell and could be problematic.

${ }^{3}$ Recent reevaluation of the taxa Strombus gigas suggests that is should be reclassified as "Eustrombus gigas." It is reported here as "Strombus (Eustrombus) gigas" to better follow the current standard taxonomic division.
} 


\section{RESEARCH BACKGROUND}

\section{Archaic Age Dates in the Antilles}

Most of the well-established (and -dated) sites during the Lithic and Archaic periods are in the Greater Antilles (Cuba, Hispaniola, Puerto Rico), Virgin Islands, and Leeward (northern) islands in the Lesser Antillean chain along with Trinidad in the south. In the Leeward (northern) islands, several Archaic sites are found on St. Thomas with 2 midpoints going back to $\sim 1090 \mathrm{BC}$ (Figueredo 1974; Lundberg 1989:34), Anguilla $(n=5) \sim 1550$ BC (Crock et al. 1995), Barbuda $(n=1)$ at 1850 BC (Watters et al. 1992), St. Maarten $(n=2)$ at $~ 3300-3000$ BC (Knippenberg 1995; Hofman and Hoogland 1999; Bonnissent et al. 2004; Bonnissent 2008), St. Kitts $(n=2)$ possibly to between 2100-2500 BC (Armstrong 1980; Wilson 1999), Saba $(n=1)$ at 1760 BC (Hofman and Hoogland 2003; Hofman et al. 2006), Nevis $(n=2)$ around 700 BC (Wilson 1989), and Antigua where over 50 Archaic sites have been identified going back to as early as $3000 \mathrm{BC}$. This is likely related to Antigua having an abundance of tool-quality chert that was heavily exploited and transported and/or exchanged to other islands (Nodine 1990; Davis 1993, 2000). There are also a number of Archaic sites on Puerto Rico that extend back to between $\sim 4800$ and 2000 BC, including Maruca that dates to 2870-2680 cal BC (see Rodríguez Ramos 2001:30), Paso del Indio to 2000 BC (Rodríguez Ramos et al. 2008:52), Angostura at 4800 BC, and the Laguna Tortuguero site, which contains paleoenvironmental evidence suggesting fire from agricultural activities dating back to around 3500-3100 BC (Burney and Burney 1994). It should be noted that there are dates on Cuba ( $\sim 5300$ $\mathrm{BC})$ and Hispaniola $(\sim 400 \mathrm{BC})$ that are roughly contemporaneous with the oldest dates on Puerto Rico (see Rodríguez Ramos et al., forthcoming). In general, there are a cluster of islands in the northern Lesser Antilles that have fairly secure dates going back to as early as 2000-3000 BC.

\section{Barbados Environment and Archaeology}

Barbados is the easternmost island in the Antilles chain. In contrast to the largely volcanic islands in the southern Lesser Antilles, Barbados is comprised almost entirely of nonvolcanic sedimentary rocks, $85-90 \%$ of which are Pleistocene reef limestones (see Donovan and Harper 2009:151) with the exception of some volcanic ashes in the northeastern Scotland district. As a result, the island is relatively flat compared to others in the Lesser Antilles, with the Scotland district having the only real pronounced topography (Humphrey 1997; Donovan and Harper 2009).

The Heywoods site is located on the northwestern part of Barbados just north of Speightstown. It was first investigated by Drewett (1991) in 1986 who noted similarities between this and other sites on the island such as Chancery Lane and Silver Sands, which were dated to the Ceramic Age (about post-500/400 BC). The site covered an area of $\sim 4500 \mathrm{~m}^{2}$, stretching $300 \mathrm{~m}$ along the coast and roughly $150 \mathrm{~m}$ inland. Heywoods was known to have been cultivated heavily for sugarcane historically and impacted by road construction, which led to an observable mixing of shallow subsurface deposits.

A subsequent investigation in 1991 was the first to reveal evidence of a possible Archaic occupation on the island. Queen conch shells and 2 adzes made from the same material were found in contexts 7 and 8 in Trench 39, with 1 specimen ${ }^{14} \mathrm{C}$ dated to $3980 \pm 100$ (I-16,840) and reported as dating to between 1750-1510 BC (Drewett 2006:204). Later, salvage recovery at the site between 1995-1999 as a result of the proposed Port St. Charles marina and resort led to the recovery of an astounding array of cultural materials mostly dating to the Ceramic Age, including abundant food refuse, human burials, decorated pottery, some beautiful examples of ceramic pot-stacks used to line wells for accessing freshwater, and preserved wooden posts, some of which retained visible adze marks 
(Drewett 2000:33, 2007). Although the purpose of this study is not to review the findings at Heywoods, it is clear that from investigations initiated by Drewett (2007) at the site over several field seasons, that it was one of the largest prehistoric villages on Barbados, but which has now been largely destroyed by developmental activities.

\section{MATERIALS AND METHODS}

In an attempt to verify an Archaic age for Heywoods, 2 Queen conch (S. [Eustrombus] gigas) samples from Trench 39 at Heywoods were submitted to Beta Analytic for ${ }^{14} \mathrm{C}$ dating. The first (Beta297521) came from a shell adze in Context 7 (Figure 2), while the other was a juvenile specimen (Beta-297522) taken from Context 8, the same stratigraphic deposit from which Drewett (1995, 2007) had obtained the initial Archaic Age date (I-16,840) (Table 1). The latter specimen, originally sent to Beta Analytic for conventional radiometric dating, instead required that the sample be dated with accelerator mass spectrometry (AMS) given that a significant amount of carbonate cement was adhered to the shell and may not have been of the same age.

Table 1 Archaic Age ${ }^{14} \mathrm{C}$ dates from Trench 39 at the Heywoods site, Barbados. All dates calibrated with CALIB 6.0 (www.calib.org) using the Marine09 data set (Reimer et al. 2009) with no local reservoir correction applied.

\begin{tabular}{|c|c|c|c|c|c|c|c|c|}
\hline Lab nr & Type & $\begin{array}{l}\text { Dating } \\
\text { method }\end{array}$ & Species & Context & $\begin{array}{l}\text { cm below } \\
\text { surface }\end{array}$ & $\begin{array}{l}{ }^{13} \mathrm{C} /{ }^{12} \mathrm{C} \\
\text { ratio }\end{array}$ & ${ }^{14} \mathrm{C} \mathrm{a}$ & cal age $(2 \sigma)$ \\
\hline $\begin{array}{l}\text { Beta- } \\
297521\end{array}$ & nell & $\overline{\text { onv }}$ & $\begin{array}{l}\text { E. gigas } \\
\text { (adze) }\end{array}$ & 7 & & +0.1 & 423 & 253 \\
\hline Beta- & Shell & AMS & $\begin{array}{l}\text { E. gigas } \\
\text { (juvenile) }\end{array}$ & 8 & $\sim 140$ & +0.4 & 436 & 328 \\
\hline I- 16,840 & Shell & Conv. & E. gigas & 8 & $\sim 140-150$ & - & $3980 \pm 100$ & $2320-1750 \mathrm{BC}$ \\
\hline
\end{tabular}

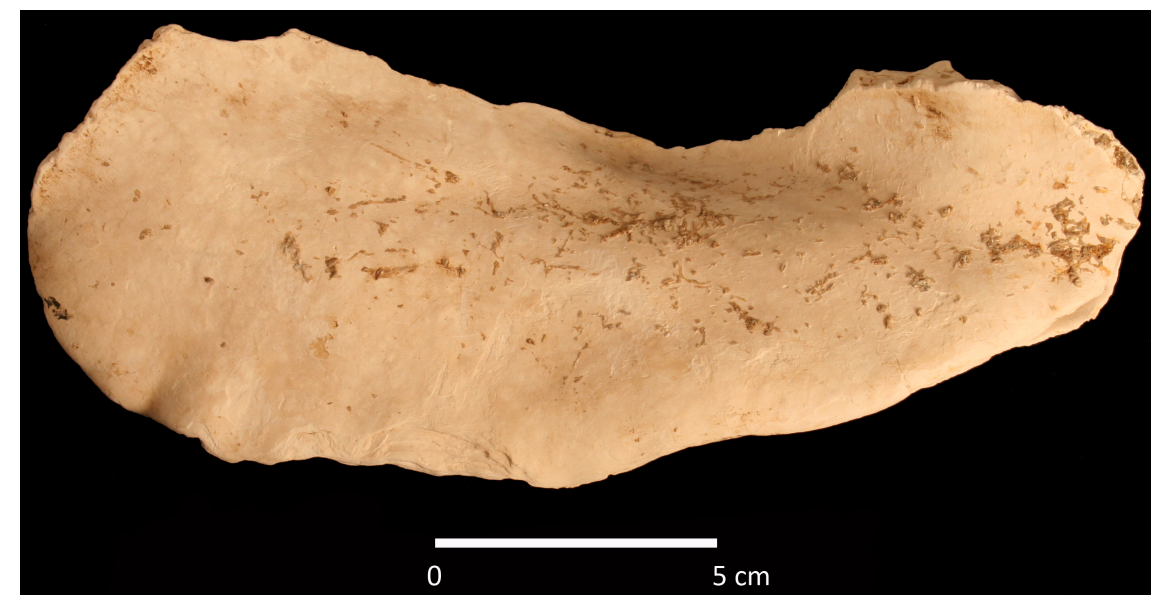

Figure 2 Shell adze dated from Context 7 in Trench 39 (Beta-297521) at the Heywoods site, Barbados

All samples were calibrated with CALIB 6.0 using the Marine09 data set (Reimer et al. 2009). Unfortunately, there are very few $\Delta \mathrm{R}$ offsets for the Caribbean, though samples from Venezuela (Hughen et al. 1996), Jamaica, the Bahamas (Broecker and Olsen 1961), and Puerto Rico (Kilbourne et al. 2007) suggest the $\Delta \mathrm{R}$ is minimal. The regional average for the Caribbean, including the Florida Keys and those along the northern South American coast, currently has a weighted $\Delta \mathrm{R}$ mean 
of $15 \pm 40$ (see www.qub.ac.uk/arcpal/marine). Due to the paucity of $\Delta \mathrm{R}$ offsets in the Antilles, none of which are in close proximity to Barbados, a $\Delta \mathrm{R}$ was not included in the calibrations. It is widely known, however, that it can be significant (see Ascough et al. 2005a,b) and future research on the subject would surely be productive in attempting to discern what the $\Delta \mathrm{R}$ is for Barbados and other islands in the Caribbean.

\section{RESULTS}

The first sample (Beta-297521) from the shell adze in Context 7 was dated conventionally to $4230 \pm$ 50 BP with an age range of 2530-2220 cal BC $(2 \sigma)$. The other juvenile Queen conch specimen (Beta-297522) was dated by AMS to $4780 \pm 40 \mathrm{BP}$ with an age range of 3280-2940 cal BC. Additionally, the original sample reported by Drewett (2006:212) as having a calibrated range of 17501510 BC with a "[median] calibrated age of 1630 BC" (2007:9) was recalibrated to 2320-1750 BC $(2 \sigma)$, indicating that the sample is older than originally reported and overlaps with the adze from Context 7 (Figure 3).

Archaic Age Dates from Heywoods, Barbados

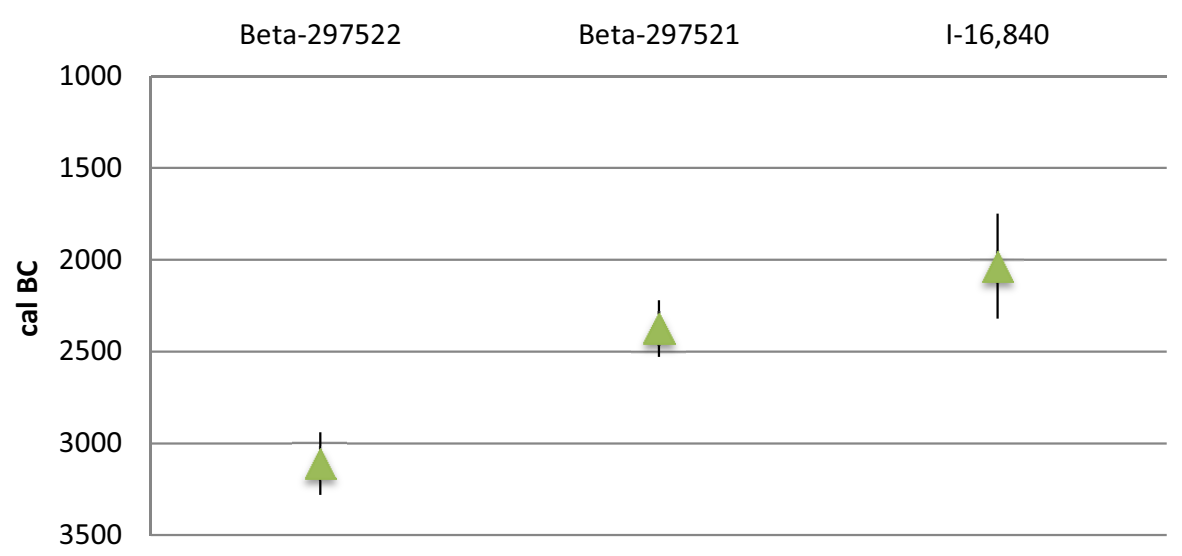

Figure 3 Statistical ranges $(2 \sigma)$ for Archaic Age dates from Heywoods, Barbados

The 3 dates from contexts 7 and 8 in Trench 39 at Heywoods support an Archaic Age for the site. Interestingly, the shorter-lived juvenile Queen conch shell from the lowest context is the oldest date for any Archaic site in the Lesser Antilles between Trinidad and Puerto Rico, spanning a distance of over $1000 \mathrm{~km}$ across dozens of islands. Under criteria established for chronometric hygiene (Fitzpatrick 2006), this sample would be considered valid given that it is 1 of 2 dates from the same context (stratum). However, the date is about 500-600 yr older $(2 \sigma)$ than the other 2 dates from the site, as well as most of the other Archaic Age dates between Trinidad and Puerto Rico. As such, it would be prudent under the circumstances to confirm this with additional AMS dates on other associated samples. Overall, the average for all 3 dates is $2710-2300 \mathrm{BC}$ and the average of the 2 youngest is 2430-1990 BC, the latter of which are relatively contemporaneous with the earliest Archaic dates found in the northern Antilles.

\section{DISCUSSION AND CONCLUSIONS}

Callaghan (2010:133) noted that the "paucity of [Archaic] sites south of Guadeloupe Passage is puzzling." Prior to this study, only a single Archaic Age ${ }^{14} \mathrm{C}$ assay was available in the southern Lesser 
Antilles that attested to the antiquity of this colonization. Given the issues associated with reliance on a single date (Fitzpatrick 2006) to establish the antiquity of a cultural horizon, particularly when that sample could originate from an older shell intermixed with later material (the "old shell" problem; see Rick et al. 2005) and which was also in a depositional environment that could have led to carbonate encrustations on a sample being incorporated into the dating of the actual shell-it was critical to verify the age of the proposed Archaic occupation at Heywoods.

The 2 additional dates support an Archaic Age occupation on Barbados. One of the samples (Beta297522) dating to 3280-2940 cal BC ( $2 \sigma$ ) may also represent the earliest colonization of the Lesser Antilles and effectively extend the temporal range of Archaic occupation by several centuries. This date should still be viewed cautiously given the possibility of having dated an older shell. However, this would seem a more plausible scenario with an artifact such as an adze where larger and more durable shells were preferred, as opposed to a juvenile shell likely representing food refuse.

Barbados is currently the only island south of the Guadeloupe Passage - apart from a scattering of reported, but poorly investigated and undated, sites - to have evidence of an Archaic Age occupation. Callaghan's (2010) examination of this phenomenon led him to look at various lines of evidence to explain why this may have been the case, including seafaring conditions that could have limited the movement of settlers as well as active volcanism, particularly in the southern Antilles, that may have prevented or dissuaded settlement and had the effect of masking earlier Archaic sites. Based on his analysis, Callaghan (2010) suggested that the dearth of Archaic sites south of the Guadeloupe Passage was not related to: 1) any oceanographic conditions or technological deficiencies in seafaring; 2) volcanism, though it was noted that prehistorically the southern Lesser Antilles were much more volcanically active; or 3) volcanic activity that may have buried earlier Archaic sites. Given the presence of a more rigorously dated site on Barbados - which now seems to confirm that the island does indeed have an Archaic Age settlement- - the question remains as to why this is the case.

Callaghan (2010:144) proposed that belief systems and fear kept peoples in the northern Antilles from settling in the southern islands and peoples from Trinidad and Tobago or the South American mainland of moving to the northwest. This is difficult to test archaeologically. However, if there is some substance to the notion that volcanism played a role in dissuading peoples from settling the Lesser Antilles, the fact that Barbados is a predominantly limestone and comparatively low-relief island may have been a reason why we see Archaic settlement here and not other similarly large, but volcanic islands in the region such as Dominica, St. Lucia, St. Vincent, or Grenada. The possibility also exists that sea-level changes during the juncture of the Middle to Late Holocene has obscured and/or eroded Archaic sites along coastal areas, though this would not necessarily explain why coastal Archaic sites are found in the northern Antilles and not the south.

The question also remains as to why the Heywoods site lacks the typical Archaic lithic tool kit seen on Trinidad, Tobago, Puerto Rico, and other islands in the Lesser Antilles. A distinct possibility is that since one of the Barbados dates (Beta-297522) is the earliest yet known for this part of the Caribbean (3280-2940 cal BC), that this Archaic group: 1) had not developed a tool kit that relied exclusively on lithic material; or 2) was flexible enough (or were forced) to use shell instead of tool quality stone, which is uncommon in Barbados given its predominantly limestone geology. Only further archaeological survey in the southern Caribbean, which to date has received relatively little attention by archaeologists compared to the northern Leeward Islands, will help resolve longstanding issues on how Archaic groups and subsequent populations eventually colonized and permanently settled these islands. 


\section{ARCHAEOLOGICAL SAMPLES}

I-81640, Heywoods

This conventional determination was obtained from a Queen conch (S. [Eustrombus] gigas) shell recovered by Drewett (2007) from Trench 39, Context 8, at a depth of $\sim 140-150 \mathrm{~cm}$ bs. The specimen was one of several found in the deposit that also included some mixing of later post-500 BC ceramic material. Calibrated date range at $\mathbf{2} \sigma: \mathbf{2 3 2 0}-\mathbf{1 7 5 0} \mathbf{B C}$.

\section{Beta-297521, Heywoods}

This conventional determination was obtained from a portion of Queen conch (S. [Eustrombus] gigas) shell adze ( $46 \mathrm{~g}$ ) recovered from Trench 39 , Context 7 , at a depth of $\sim 130 \sim 140 \mathrm{~cm}$ bs. The artifact was one of several found in this stratum. Calibrated date range at $2 \sigma: \mathbf{2 3 5 0 - 2 2 2 0}$ BC.

Beta-297522, Heywoods

This AMS determination was obtained from a portion of juvenile Queen conch (S. [Eustrombus] gigas) ( $72 \mathrm{~g}$ ) recovered from Trench 39, Context 8 , at a depth of $\sim 140-150 \mathrm{~cm}$ bs. The specimen was one of numerous found in this stratum. Calibrated date range at $2 \sigma: 3280-2940 \mathrm{BC}$.

\section{ACKNOWLEDGMENTS}

This research was funded by a 2010 Faculty Research Award from the Department of Sociology and Anthropology at North Carolina State University. Thanks go to Alissandra Cummins, Thomas Loftfeld, and Kevin Farmer at the Barbados Museum and Historical Society for facilitating and permitting the collection of samples. NCSU students Jessica Stone, Meagan Clark, and Max Sherard assisted in sampling at the museum. Comments from Peter Drewett, Bill Keegan, Reniel Rodríguez Ramos, and an anonymous reviewer helped to improve the content of the paper.

\section{REFERENCES}

Allaire L, Mattioni M. 1983. Boutbois et Le Godinot: Deux gisements acéramiques de la Martinique. In: Allaire L, Mayer F-M, editors. Proceedings of the IX International Congress for the Study of the Pre-Columbian Cultures of the Lesser Antilles. Santo Domingo, Dominican Republic. Montreal: Centre de Recherches Caraibes. p 27-38.

Armstrong D. 1980. Shellfish gatherers of St. Kitts: a study of Archaic subsistence and settlement patterns. In: Lewenstein S, editor. Proceedings of the Eighth International Congress for the Study of the Pre-Columbian Cultures of the Lesser Antilles. Anthropological Research Papers 22. Tempe: Arizona State University. p 152-67.

Ascough P, Cook GT, Dugmore AJ. 2005a. Methodological approaches to determining the marine radiocarbon reservoir effect. Progress in Physical Geography 29(4):532-47.

Ascough P, Cook GT, Dugmore AJ, Scott M, Freeman S. $2005 \mathrm{~b}$. Influence of mollusk species on marine $\Delta \mathrm{R}$ determinations. Radiocarbon 47(3):433-40.

Bonnissent D. 2008. Archéologie précolombienne de l'île de Saint-Martin, Petites Antilles (3300 BC - 1600
AD) $[\mathrm{PhD}$ thesis]. Universite Aix-Marseille I, Université de Provence.

Bonnissent D, Bertran P, Serrand N. 2004. Le gisement précéramique de la Baie orientale à Saint-Martin (Petites Antilles). In: Demoule J-P, editor. La France archéologique: vingt ans d'aménagements et de découvertes. Vanves: Hazan. p 236-7.

Boomert A. 2000. Trinidad, Tobago, and the Lower Orinoco Interaction Sphere: An Archaeological/Ethnohistorical Study. Alkmaar: Plantijn Casparie Heerhugowaard B.V.

Broecker WS, Olson EA. 1961. Lamont radiocarbon measurements VIII. Radiocarbon 3:176-204.

Burney DA, Burney LP. 1994. Holocene charcoal stratigraphy from Laguna Tortugeuro, Puerto Rico, and the timing of human arrival on the island. Journal of Archaeological Science 21(2):273-81.

Callaghan R. 2001. Ceramic age seafaring and interaction potential in the Antilles: a computer simulation. Current Anthropology 42:308-13.

Callaghan R. 2003. Comments on the mainland origins of the preceramic cultures of the Greater Antilles. Latin American Antiquity 14:323-38. 
Callaghan R. 2010. Crossing the Guadeloupe passage in the Archaic Age. In: Fitzpatrick SM, Ross A, editors. Island Shores, Distant Pasts: Archaeological and Biological Perspectives on the Pre-Columbian Settlement of the Caribbean. Gainesville: University Press of Florida. p 127-47.

Crock JG, Petersen JB, Douglas N. 1995. Preceramic Anguilla: a view from the Whitehead's Bluff site. In: Alegría R, Rodríguez M, editors. Proceedings of the XVth International Congress of Caribbean Archaeology. San Juan: Centro de Estudios Avanzados de Puerto Rico y el Caribe. p 283-94.

Davis DD. 1993. Archaic blade production on Antigua, West Indies. American Antiquity 58:688-97.

Davis DD. 2000. Jolly Beach and the Preceramic Occupation of Antigua, West Indies. Yale University Publications in Anthropology 84. New Haven: Yale University Press.

Donovan K, Harper DAT. 2009. Geological entities explained 2: Barbados. Geology Today 25:151-8.

Drewett P. 1991. Prehistoric Barbados. London: Archetype Publications.

Drewett P. 1993. Excavations at Heywoods, Barbados, and the economic basis of the Suazoid period in the Lesser Antilles. Proceedings of the Prehistoric Society 59:113-37.

Drewett P, editor. 2000. Prehistoric Settlements in the Caribbean: Fieldwork in Barbados, Tortola, and the Cayman Islands. London: Archetype Publications.

Drewett P. 2006. Dating the prehistoric settlement of Barbados. Journal of the Barbados Museum and Historical Society LII:202-14.

Drewett PL. 2007. Above Sweet Waters: Cultural and Natural Change at Port St Charles, Barbados, c.1750 $B C-A D$ 1850. London: Archetype Publications.

Figueredo AE. 1976. Caño Hondo, un residuario preceramico en la isla de Vieques. In: Proceedings of the Sixth International Congress for the Study of Pre-Columbian Cultures of the Lesser Antilles (Guadeloupe 1975). Société d'Histoire de la Guadeloupe, Pointe-àPitre. p 247-52.

Fitzpatrick SM. 2006. A critical approach to ${ }^{14} \mathrm{C}$ dating in the Caribbean: using chronometric hygiene to evaluate chronological control and prehistoric settlement. Latin American Antiquity 17:389-418.

Fitzpatrick SM, Giovas C. 2011. New radiocarbon dates for the Grenadine Islands, West Indies. Radiocarbon 53(3):451-60.

Fitzpatrick SM, Kappers M, Kaye Q, Giovas C, LeFebvre M, Harris MH, Burnett S, Pavia JA, Marsaglia K, Feathers J. 2009. Precolumbian settlements on Carriacou, West Indies. Journal of Field Archaeology 34: 247-66.

Fitzpatrick SM, Kappers M, Giovas C. 2010. The southward route hypothesis: examining Carriacou's chronological position in Antillean prehistory. In: Fitzpatrick SM, Ross AH, editors. Island Shores, Distant
Pasts: Archaeological and Biological Approaches to the Pre-Columbian Settlement of the Caribbean. Gainesville: University Press of Florida. p 163-76.

Hackenberger S. 1991. Archaeological test excavation of Buccament Valley Rockshelter, St. Vincent: preceramic stone tools in the Windward Islands, and the early peopling of the eastern Caribbean. In: Pantel TA, Vargas AI, Sanoja OM, editors. Proceedings of the XIII International Congress for Caribbean Archaeology. Curaçao: International Association for Caribbean Archaeology. p 86-91.

Hofman CL, Hoogland MLP. 1999. Archaeological investigations on St. Martin (Lesser Antilles). Leiden: Faculty of Archaeology, Leiden University.

Hofman CL, Hoogland MLP. 2003. Plum piece: evidence for Archaic seasonal occupation on Saba, northern Lesser Antilles, around 3300 BP. Journal of Caribbean Archaeology 4:1-16.

Hofman CL, Bright AJ, Hoogland MLP. 2006. Archipelagic resource procurement and mobility in the northern Lesser Antilles: the view from a 3000-year-old tropical forest campsite on Saba. Journal of Island and Coastal Archaeology 1:145-64.

Hughen KA, Overpeck JT, Peterson LC, Anderson RF. 1996. The nature of varved sedimentation in the Cariaco Basin, Venezuela, and its palaeoclimatic significance. In: Kemp AES, editor. Palaeoclimatology and Palaeoceanography from Laminated Sediments. London: Geological Society Special Publication No. 116. p 171-83.

Humphrey J. 1997. Geology and hydrogeology of Barbados. In: Vacher HL, Quinn T, editors. Geology and Hydrology of Carbonate Islands. Developments in Sedimentology 54. Amsterdam: Elsevier.

Keegan WF. 1994. West Indian archaeology 1. Overview and foragers. Journal of Archaeological Research 2: 255-84.

Keegan WF. 1995. Modeling dispersal in the prehistoric West Indies. World Archaeology 26:400-20.

Keegan WF. 2000. West Indian archaeology 2. Ceramic Age. Journal of Archaeological Research 8:135-67.

Kilbourne KH, Quinn TM, Guilderson TP, Webb RS, Taylor FW. 2007. Decadal- to interannual-scale source water variations in the Caribbean Sea recorded by $\mathrm{Pu}-$ erto Rican coral radiocarbon. Climate Dynamics 29: 51-62.

Knippenberg S. 1995. Norman Estate and Anse des Peres: two Precolumbian sites on St. Martin [unpublished Master's thesis]. Leiden: Leiden University.

Lalueza-Fox C, Gilbert MTP, Martínez-Fuentez AJ, Calafell F, Bertanpetit J. 2003. Mitochondrial DNA from Pre-Columbian Ciboneys from Cuba and the prehistoric colonization of the Caribbean. American Journal of Physical Anthropology 121:97-108.

Lundberg ER. 1989. Preceramic procurement patterns at Krum Bay, Virgin Islands [unpublished $\mathrm{PhD}$ dissertation]. University of Illinois, Urbana-Champagne. Ann 
Arbor: University Microfilms.

Nodine BK. 1990. Aceramic interactions in the Lesser Antilles: evidence from Antigua, West Indies. Paper presented at the 55th Annual Meeting of the Society for American Archaeology, Las Vegas.

Petersen JB, Hofman CL, Curet AL. 2004. Time and culture: chronology and taxonomy in the eastern Caribbean and the Guianas. In: Delpuech A, Hofman CL, editors. Late Ceramic Age Societies in the Eastern Caribbean. Oxford: British Archaeological Reports Series 1273. p 17-32.

Reimer PJ, Baillie MGL, Bard E, Bayliss A, Beck JW, Blackwell PG, Bronk Ramsey C, Buck CE, Burr GS, Edwards RL, Friedrich M, Grootes PM, Guilderson TP, Hajdas I, Heaton TJ, Hogg AG, Hughen KA, Kaiser KF, Kromer B, McCormac FG, Manning SW, Reimer RW, Richards DA, Southon JR, Talamo S, Turney CSM, van der Plicht J, Weyhenmeyer CE. 2009. IntCa109 and Marine09 radiocarbon age calibration curves, 0-50,000 years cal BP. Radiocarbon 51(4): 1111-50.

Richard G. 1994. Premier indice d'une occupation précéramique en Guadeloupe continentale. Journal de la Société des Américanistes 80:241-2.

Rick T, Vellanoweth R, Erlandson JM. 2005. Radiocarbon dating and the "old shell" problem: direct dating of artifacts and cultural chronologies in coastal and other aquatic regions. Journal of Archaeological Science 32(11):1641-8.

Rodríguez Ramos R. 2001. Lithic reduction trajectories at La Hueca and Punta Candelero sites, Puerto Rico [unpublished Master's thesis]. College Station: Department of Anthropology, Texas A\&M University.

Rodríguez Ramos R, Babilonia E, Curet LA, Ulloa J. 2008. The pre-Arawak pottery horizon in the Antilles: a new approximation. Latin American Antiquity 19: 47-63.

Rodríguez Ramos R, Pagán Jiménez J, Hofman C. Forthcoming. Chapter 9: The Humanization of the Insular Caribbean. Handbook of Caribbean Archaeology. Oxford: Oxford University Press.

Rouse I. 1986. Migrations in Prehistory: Inferring Population Movement from Cultural Remains. New Haven: Yale University Press.

Rouse I. 1992. The Tainos: Rise and Decline of the People Who Greeted Columbus. New Haven: Yale University Press.

Steadman DW, Stokes A. 2002. Changing exploitation of terrestrial vertebrates during the past 3000 years on Tobago, West Indies. Human Ecology 30:339-67.

Watters DR, Donahue J, Stuckenrath R. 1992. Paleoshorelines and the prehistory of Barbuda, West Indies. In: Johnson L, Stright M, editors. Paleoshorelines and Prehistory. Boca Raton: CRC Press. p 15-52.

Wilson S. 1989. The prehistoric settlement pattern of Nevis, West Indies. Journal of Field Archaeology 16: $427-50$.

Wilson S. 2007. The Archaeology of the Caribbean. Cambridge: Cambridge University Press.

Wilson S, Iceland HB, Hester TR. 1998. Preceramic connections between Yucatan and the Caribbean. Latin American Antiquity 9:342-52. 